\title{
Deafness and Child Development
}





\section{Deafness and Child Development \\ Kathryn P. Meadow}

UNIVERSITY OF CALIFORNIA PRESS Berkeley I Los Angeles 
University of California Press

Berkeley and Los Angeles, California

(C)1980 by

The Regents of the University of California

Printed in the United States of America

\section{Library of Congress Cataloging in} Publication Data

Meadow, Kathryn $P$

Deafness and child development.

Includes bibliographical references and indexes.

1. Children, Deaf. 2. Child

development. I. Title. [DNLM:

1. Deafness - In infancy and childhood. 2. Child development.

3. Deafness-Complications.

4. Child development

deviations-Etiology. WV271

M482d]

HV2380.M4 155.4'514 74-81435

ISBN 0-520-02819-8 
For my parents

Wilma Karnes Pendleton

Orien A. Pendleton (1899-1975)

and my children

Lynn Elizabeth Meadow

Robert Keith Meadow 
